Florida International University FIU Digital Commons

6-3-1981

\title{
Development of an instrument for the evaluation of weight reduction advice in women's magazines
}

Sheryl H. Calish

Florida International University

DOI: $10.25148 /$ etd.FI14052540

Follow this and additional works at: https://digitalcommons.fiu.edu/etd

Part of the Dietetics and Clinical Nutrition Commons

\section{Recommended Citation}

Calish, Sheryl H., "Development of an instrument for the evaluation of weight reduction advice in women's magazines" (1981). FIU Electronic Theses and Dissertations. 1976.

https://digitalcommons.fiu.edu/etd/1976 
FLORIDA INTERNATIONAL UNIVERSITY

DEVELOPMENT OF AN INSTRUMENT FOR THE EVALUATION OF WEIGHT REDUCTION ADVICE IN WOMEN'S MAGAZINES

\author{
A THESIS \\ SUBMITTED IN PARTIAL REQUIREMENT \\ FOR COMPLETION OF \\ MASTER OF SCIENCE DEGREE \\ DEPARTMENT OF DIETETICS AND NUTRITION \\ BY \\ SHERYL H. CALISH \\ MIAMI, FLORIDA
}

APRIL 1981 


\begin{abstract}
DEVELOPMENT OF AN INSTRUMENT FOR THE EVALUATION OF WEIGHT REDUCTION ADVICE IN WOMEN'S MAGAZINES
\end{abstract}

by

Sheryl H. Calish

The purpose of this study was to develop a valid and reliable instrument to evaluate the weight reduction advice in popular women's magazines. An apparent proliferation of articles on weight reducation in the mass media and women's magazines have been critized as faddist by some professionals. Regardless of this concern, a standardized method of evaluating any diet remains noexistent.

To achieve the purpose the study was conducted in three parts: a Field Test, a Validity study and a Reliability Study. An Article Evaluation form, which listed the negative characteristics of a faddist weight reduction article was constructed as the instrument. The characteristics were developed by reviewing various 
critiques of popular weight reduction regimens in the literature and selecting negative items from those critiques. The Article Evaluation was evaluated by requiring experts to rate the importance of each characteristic. Both forms were revised based on the results of the Field Test. The Validity study was conducted by selecting 30 experts, at random, from a list of all experts who had authored or co-authored an article published in the 1979 issues in one of three professional journals in the nutrition field, and having them complete a revised Instrument Evaluation form.

The Reliability study consisted of having three local dietitians with Master of Science degrees rate the same eight articles from popular women's magazines using the revised Article Evaluation form. The data was analyzed using the Friedman Two-way Analysis of Varience (ANOVA). The results of the validity study indicated that all thirteen characteristics were either somewhat or very important. Based on this, it was concluded that the instrument was valid. The results of the Reliability Study indicated that, except for one characteristic, there was no statistically significant difference at the .10 level $(d f=2)$ in the evaluations of the raters, therefore it was concluded that the instrument was reliable. 
To Professors Curry, Himburg and Morrow

This thesis, having been approved in respect to form and mechanical execution, is referred to you for judgment upon its substantial merit.

Sch6ol of Technology

The thesis of Sheryl H. Calish is approved.

$$
\text { erofessor }
$$

Professor

Professhr

Date of Examination: (pene $3 / 40 /$ 
TABLE OF CONTENTS

Chapter

Page

I. INTRODUCTION • • • • • • • • • • • • • • • 1

The Problem . . . . . . . . . . . . 1

Questions................ . 3

Definition of Terms . . . . . . . . . 3

Limitations . . . . . . . . . . . . 4

II. REVIEW OF THE LITERATURE • . • . • . . . . . 5

Introduction . . . . . . . . . . . 5

Faddism . . . . . . . . . . . . 8

Historical Aspects of Faddism . . . . . 10

Current Theories of Weight Loss . . . . . 15

Nutritional knowledge of Consumers. . . . 19

The Rating scale as a

Method of Evaluation. ........ 24

Summary ............... 27

III. METHODOLOGY. • . . . . . . . . . . . 29

Field Test .............. 29

Validity Study. . . . . . . . . . 31

Reliability study . . . . . . . . . 32

IV. RESULTS AND DISCUSSION . . . . . . . . . . 34

Field Test. . . . . . . . . . . 34

Validity Study. . . . . . . . . . . 35

Reliability study ........... 40

V. SUMMARY AND CONCLUSIONS. . . . . . . . . . 45

APPENDIX A • . . . . . . . . . . . . . 49

AP PENDIX B . . . . . . . . . . . . . . . . 50

APPENDIX C . . . . . . . . . . . . . . . 54

SELECTED REFERENCES. • . • . . • • • • • • . 57 


\section{LIST OF TABLES}

Table

Title

Page

1

Composite Ratings of

Experts on the

Instrument Evaluation. . . . . .

2

Results of Friedman

Two-Way Analysis of

Varience . • • • • • • • • • • • • •

3

List of Characteristics

According to Chi-Square

values... . . . . . . . . 
CHAPTER I

\section{INTRODUCTION}

\section{The Problem}

An increased concern for the possible health risks attributed to obesity has inspired a proliferation of weight reduction regimens and advice published in the popular magazines in the United States. ${ }^{1}$ Huge amounts of money have been spent on these weight reduction regimens and plans with little more than temporary results. 2 Women's magazines, as an example of popular magazines, frequently contain articles on weight reduction advice that may be valid or "faddist" in nature. Furthermore, in the 1978 April, August, and December issues of six popular women's magazines, a total of ten articles on

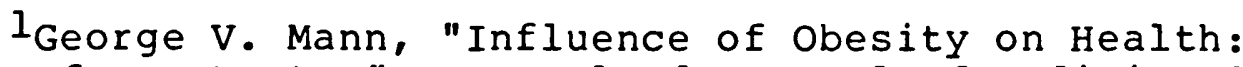
First of Two Parts," New England Journal of Medicine 291 (July 25, 1974):179.

2 Frank I. Tullis and Kenneth F. Tullis, "Chapter 25. Obesity," in Nutritional Support of Medical Practice, pp. 392-406, eds. Howard A. Schneider, Carl E. Anderson and David B. Coursin (New York: Harper \& Row, Publishers, 1977); Ercel Eppright, Mattie Pattison and Helene Barbour, Teaching Nutrition, 2nd ed. (Iowa: Iowa State University Press, 1963), pp. 64-65; Ruth Baker and C. L. Brumback, "Public Health and the Practicing Physician-Partners in Community Nutrition," Journal of the Florida Medical Association 66 (April 1979):456-459. 
general nutrition advice were published. ${ }^{1}$ At the same time that these articles are being published, professionals concerned with the prevalence of fad diets have published articles criticizing them and warning of their futile nature while only briefly mentioning the role of the popular literature in perpetuating facts or fallacies about diet and nutrition. ${ }^{2}$

The basis for criticizing any diet remains fuzzy and subjective because a standardized method of evaluation is nonexistent. To aid in the nutrition education of consumers, an objective measure that is reliable and valid is needed to determine when one is reading a "fad diet."

\section{Purpose}

The purpose of this study was to develop a valid and reliable instrument to evaluate the weight reduction advice in popular women's magazines.

${ }^{1}$ Family Circle, 24 April, 7 August, 15 December 1978; Good Housekeeping, April, August, December 1978; Harper's Bazarr, April, August, December 1978; The Ladies' Home Journal, April, August, December 1978; Redbook, April, August, December 1978; Woman's Day, 7 August, 19 December 1978 .

2 William J. Darby, "The Unicorn and Other Lessons from History," Nutrition Reviews 341 , supplement July 1974):57-61; "Food Faddism" Nutrition Reviews 341, supplement (July 1974):53-56; Jean Mayer, "Weight Control and 'Diets' Facts and Fads," in The Health Robbers, eds. Stephen Barrett and Gilda Knight (Philadelphia: George F. Stickley Company, 1976), pp. 47-59; Eppright et al., Teaching Nutrition, pp. 64-65; Theodore Berland and the Editors of Consumer Guide, Rating the Diets (Skokie, Ill.: Publications International Ltd., 1979; The New American Library, Inc., 1979), pp. 118-122. 


\section{Questions}

In order to achieve the purpose the study was designed to answer the following questions:

1. What characteristics should be part of an instrument used to evaluate articles on weight reduction advice?

2. What is the content validity of an instrument developed to evaluate articles on weight reduction advice?

3. What is the degree of consistency among raters using a rating scale developed to evaluate weight reduction articles from popular women's magazines?

\section{Definition of Terms}

reactor - a member of one of three state universities who teaches in the Food, Nutrition and/or Home Economics and/ or Dietetics department of one of these universities. A person meeting this criterion was used in the Field Test. expert - people who have authored or co-authored an article for the Journal of The American Dietetic Association, the Journal of Nutrition Education or the American Journal of Clinical Nutrition. People meeting this criterion were used in the Validity study. rater - a Registered Dietitian with a Master of Science degree. People meeting this criterion were used in the reliability study. weight reduction article - an article in a popular women's 
magazine which contained a diet/menu plan and/or information on obesity and overweight and/or advice for following a diet plan. (Did not include articles that are only recipes, exercise plans or testimonials.)

\section{Limitations}

This study was designed as a pilot study in an area that, as far as is known, has not been studied in depth. The instrument was developed only for use on weight reduction articles in women's magazines.

At this point in its development, the instrument has been designed for use by professionals in diet and nutrition, and not for use by consumers. 
CHAPTER II

REVIEW OF THE LITERATURE

Introduction

A recent survey indicated that 62 percent of American adults were estimated to be overweight. ${ }^{1}$ The health risks attributed to obesity included increased burden to the body's frame and circulation, possible increased intake of unspecified noxious agents and promotion of glyceride synthesis and transport, and increased difficulty in maintaining activity. ${ }^{2}$

A review of the literature revealed a proliferance of weight reduction diets as evidenced by a recent rating of 75 diets. $^{3}$ The prevelence of overweight adults and the numerous weight reduction diets in the news suggest that people are concerned about their weight and interested in these popular diets. Many of these diets may be found in the pages of popular women's magazines which are widely

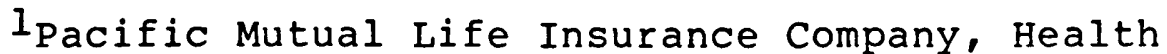
Maintenance, conducted by Louis Harris and Associates, Inc. (Newport Beach, CA: Pacific Mutual LIfe Insurance Company, 1978), p. 16.

${ }^{2}$ George V. Mann, "Influence of Obesity on Health: First of Two Parts," New England Journal of Medicine 291 (July 25, 1974):179.

${ }^{3}$ Theodore Berland and the Editors of Consumer Guide, Rating the Diets (Skokie, Ill.: Publications International Ltd., 1979: The New American Library, Inc., 1979), pp. 249-253. 
circulated. The reported circulation figures for Good Housekeeping, Family Circle, Women' Day, Harper's Bazaar, The Ladies Home Journal and Redbook totaled 27,855,787 in the United States and Canada. ${ }^{1}$ Family Circle and Women's Day had the largest reported circulation figures of $8,350,000$ and $8,000,000$, respectively. ${ }^{2}$

After estimating the nutritive value of twelve reducing diets published in magazines and newspapers, and comparing these values with the Recommended Dietary Allowances for a 25-year-old woman, Eppright et al, concluded that prolonged subsistence on some of the diets would be "deleterious to health." ${ }^{3}$ Furthermore, the frequency with which such diets have appeared in women's magazines and fail to fulfill their glowing promises has done more damage by darkening the reputation of all diets in the eyes of the dieter. ${ }^{4}$ Deutsch, Haag, and sherrill each refered to a survey of women's magazines from 1969 through 1971, which showed that over 70 diet articles

\footnotetext{
${ }^{1}$ Ulrich's International Periodical's Directory, 18 th ed.. (New York: R. R. Bowker Company, 1979-1980), pp. $415,733,735,804$, and 1688 .

2 Ibid.

${ }^{3}$ Ercel Eppright, Mattie Pattison and Helene Barbour, Teaching Nutrition, 2nd ed., (Iowa: Iowa State University Press, 1963), pp. 64-65.

${ }^{4}$ Ibid.
} 
appeared at this time. ${ }^{1}$ These diets were exemplified by titles such as "Dieting by Computer" and "Chewing Your Way to Health, Sexual Vitality, Peace." 2

Women's magazines also hold out romanticized promises or claims to their readers with some of the same diet fads found in the media. In the introduction to her article on the Scarsdale Diet, La Barre stated:

This is the no-hunger, no-hassel, diet that in-the-know big losers have been passing onto their friends coast to coast. It is the easiest diet ever... In exactly eight days I had lost exactly eight pounds. ${ }^{3}$

Critiques by professionals on the articles appearing in popular women's magazines have, for the most part, been unfavorable. Sherrill criticized the diet articles for being proliferous in quantity and giving pseudoprofessional advice. ${ }^{4}$ More specific criticism by Van Itallie was aimed at the "regimens whose inherent unpalatability is temporarily disguised by their

${ }^{1}$ Ronald M. Deutsch, The New Nuts Among the Berries (Palo Alto, CA: Bull Publishing Co., 1977), p. 230; Jessie Helen Haag, Consumer Health: Products and Services (Philadelphia: Lea \& Febiger, 1976), p. 26; Robert Sherrill, "Before You Believe Those Exercise and Diet Ads Read the Following Report," Today's Health 49 (August 1971):34-36.

2 Deutsch, Nuts Among the Berries, p. 230; Haag, Consumer Health, p. 26; Serrill, "Before you Believe Those Diet Ads," pp. 34-36.

${ }^{3}$ La Barre, "Dr. Tarnower's Superdiet," p. 74.

${ }^{4}$ Sherrill, "Before You Believe Those Diet Ads," pp. 34-35. 
novelty."l According to Eppright et al., the frequency with which diet articles have appeared and their failure in dealing with obesity may only result in discouraging the dieter. ${ }^{2}$ with respect to the diet regimens in the media Mann stated:

These permutations of fuel range from the impossible to the ridiculous. If they have any common feature it is that they make elaborate promises of success, they understate the rigors of adherence, and they try to place the decision for dietary restriction in the hands of the dieter. . . When he grows tired of the specialty food in the regimen he makes the decision to eat less. 3

The problem with many weight reduction diets found in the popular press is that they have failed to develop new eating habits and to produce more than just temporary results. 4

$\underline{\text { Faddism }}$

Although vegetarian and weight reduction diets, in and of themselves, may not be faddist, many of them have

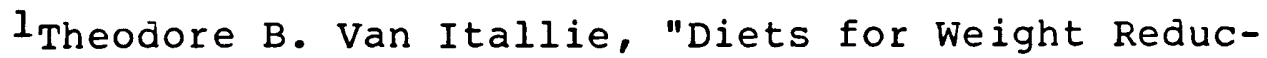
tion: Mechanisms of Action and Physiological Effects," International Journal of Obesity 2 (1978):112-122.

2Eppright et al., Teaching Nutrition, pp. 64-65

${ }^{3}$ George V. Mann, "Influence of Obesity on Health: Second of Two Parts," New England Journal of Medicine 291 (August 1, 1974):230.

${ }^{4}$ Ruth Baker and C. L. Brumback, "Public Health and the Practicing Physician - Partners in Community Nutrition," Journal of the Florida Medical Association 66

(April 1979):456-459. 
been criticized as such. Diets designed for rapid weight loss, as many fad diets may be structured, are believed to have temporary results, if any. ${ }^{l}$ These diets are reported to be characterized by an emphasis on specific foods, or foods not normally consumed; the possibility of ill side-effects after following diet advice; glowing promotions that ensure an absence of deprivation; their "bad" biochemistry; the use of testimonials in place of documented research; and claims of new revolutionary ideas, $100 \%$ success or persecution by the medical profession. ${ }^{2}$ According to nutrition professionals, nutritionally sound weight reduction regimens differ from most fad diets in that they provide balanced calorie deficits and encourage the correction of faulty food habits. 3

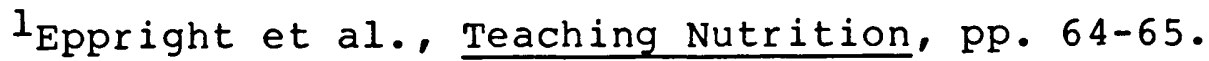

2Eppright et al., Teaching Nutrition, pp. 64-65; E. Neige Todhunter, "Food Habits, Food Faddism and Nutrition," World Review of Nutrition and Dietetics: Food Nutrition and Health 16 (1973):287-317; Baker and Brumback, "Public Health and the practicing Physician," pp. 457-462; Jean Mayer, "Weight Control and 'Diets': Facts and Fads," in The Health Robbers, eds. Stephen Barrett and Gilda Knight (Philadelphia: George F. Sitckley Company, 1976), pp. 47-59; Adelia M. Beeukes, "Characteristics of the Self-Styled Scientist," Journal of the American Dietetic Asociation 32 (July 1956):627-630.

$3_{\text {Ruth M. Leverton, "The Merry-Go-Round of Reducing }}$ Diets," Journal of The American Dietetic Association 29 (April 19530:334-336; Mayer, "Weight Control and 'Diets'," pp. 47-59. 
Historical Aspects of Faddism

Diet fads may be more numerous today. However, food faddism has played a role in man's food habits over the ages. While sensory and technological factors have played a role in the development of food habits; attitudes, religion, personal beliefs, symbolism and standards of beauty have also played a role. ${ }^{l}$ Many food myths were, and still are, a part of medical quackery in general. Young stated:

At some point primitive man began to employ the same products of nature which he used as food in a therapeutic way. The tradition thus began, with whatever mixture of empirical, religious, and magical notivations that lay behind it has persevered until today. This inextricable locking of foods and medicine is a fundamental historical force undergirding food cultism and nutrition quackery. ${ }^{2}$

Todhunter attributed the existence of "myths and fallacies about food in earlier times" in part to Hippocrates who "Wrote of the health value of certain foods, and fads of various kinds have persisted ever since." ${ }^{3}$ Hippocrates, as quoted by Deutsch, "based his whole scheme of

1Todhunter, "Food Habits, Faddism, and Nutrition," pp. 280-301; James Harvey Young, "Historical Aspects of Food Cultism and Nutrition Quackery," in symposia of the Swedish Nutrition Foundation VIII: Food Cultims and Nutrition Quackery, ed. Gunnar Blix (Uppsala, Sweden: Almqvist \& Wiksells, 1970), pp. 7-21. 10.

2young, "History of Food cultism and Quackery," p.

${ }^{3}$ Todhunter, "Food Habits, Faddism and Nutrition," p. 305 . 
treatment and prevention on what his patients ate," a tradition which lasted some 2,000 years in Western Civilization. ${ }^{1}$

While it may be understood that food faddism finds its roots in food beliefs and attitudes of earliest times, it is also interesting to note that many contemporary food fads were direct decendents of prominent faddists of the late 1700 s until the early part of this century and it is of these faddists that Deutsch wrote. ${ }^{2}$ Vegetarianism, which was prominent in many eastern and early Christian religious sects, was revived in America by Sylvester Graham, a New England minister who is associated with the cracker which carries his name. ${ }^{3}$ According to Deutsch, he was influenced by the concept of homeopathy and most importantly, by the Garden of Eden; he believed "the right food would save not only a man's life but also his soul. 4 He regarded meat, alcohol, over-indulgence in food and bread that had been robbed of its bran to be evils. ${ }^{5}$ Although Graham may have gotten carried away in "expounding on the mix of hellfire and ill health that

${ }^{1}$ Deutsch, Nuts Among the Berries, p. 19.

2Ibid., pp. 25-136.

3Todhunter, "Food Habits, Faddism and Nutrition," p. 310 .

${ }^{4}$ Deutsch, Nuts Among the Berries, pp. 25-29.

${ }^{5}$ Sylvester Graham, Lectures on the Science of Life, 2 Vols. (Boston: Marsh, Capen, Lyon and Webb, 1839) : 151-537. 
menaced the tipler" as well as the poor health habits of others, he was a positive motivator of diet and especially hygiene in a time when these practices were in poor standing. 1

The Alcott family, of whom Louisa May was a member, followed the teachings of Graham and the Bible Christians in consuming a vegetarian diet and Graham bread made without yeast or leavening. They went to the extreme, at one pont, of eating only "hard Graham break, stored apples, cooked potatoes and ice water" while extolling the tenants of self-deprivation. 2 Several year later John Harvey Kellogg of the Seventh Day Adventist Church helped to further the vegetarian principles.

Dr. Kellogg soon added a new dimension to health reform, and which foreshadowed our own day. For until his entry upon the scene . . . foodism had been based upon religious and philosophic intuition. Vegetarianism and whole grain advocacies had been born of inspiration. But John Harvey now set out to give these ideas scientific support. 3

The result of his work, and his brother's also did much to advance the cereal industry. To some, this industry "represents the first major commercial exploitation of food folklore."4 To others it was "an interesting example

${ }^{l}$ Deutsch, Nuts Among the Berries, pp. 26-3l; Todhunter, "Food Habits, Faddism and Nutrition," p. 310. 2 Deutsch, Nuts Among the Berries, pp. 37-42. ${ }^{3}$ Ibid., p. 60 . ${ }^{4}$ Young, "History of Food Cultism and Quackery," p. 18. 
of a myth created by a man who combined the qualifications of a doctor and those of a religious prophet. ${ }^{1}$

Bernard MacFadden was another vegetarian during the early part of this century who was also known as an exploiter of peoples' desire to be physically fit. Deutsch describes his contribution as follows:

He built a fortune from misinforming the public about nutrition and health. He was the first to use modern mass-media techniques in the process, setting a pattern which has endured.2

Deutsch also held that Jack LaLanne has followed MacFadden "in the best tradition," however he accepted and occasionally expounded the value of meat and vitamins in the diet whereas, for the most part, MacFadden disdained these. $^{3}$

Besides vegetarianism other contemporary fad diets also stemed from fadists in the later part of the 19 th Century and early part of the 20th Century. While the Kelloggs were busy building their cereal empire a retired, obese businessman named Horace Fletcher discovered that by eating only when one was hungry and then by chewing each bite 50 to 70 times, one could successfully lose

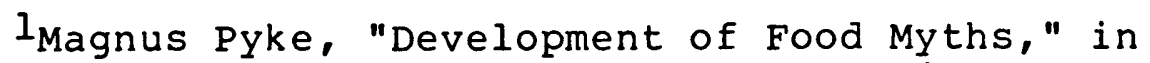
Symposia of the Swedish Nutrition Foundation VIII: Food Cultism and Nutrition Quackery, ed. Gunnar Blix (Uppsala, Sweden: Almqvist \& Wiksells, 1979), p. 25.

2 Deutsch, Nuts Among the Berries, p. 121. I Ibid., pp. 132-134. 
weight. ${ }^{1}$ This theory became known as Fletcherism and was popular at the beginning of this century. It was published by The Ladies' Home Journal in 1909 and since then has periodically found its way into many weight reduction regimens. ${ }^{2}$

The numerous low-carbohydrate diets that are popular today have also been around for a while. Their notoriety is believed to have developed when William Banting, as layman, published a pamphlet in 1864 entitled A Letter on Corpulence. ${ }^{3}$ This letter was published by Mr. Banting after successfully losing a great deal of weight on a diet low in sugar, bread and other forms of carbohydrates. Dr. Atkins, for one, referes to William Banting's work admiringly. 4 Various forms of this diet have cropped up from time top time with a frequency that astonishes the medical world. 5 Darby has summarized the status of faddism as follows:

It requires no brilliance of insight to recognize in today's promoters of food cultism and nutritional hogwash the same devices that have characterized medical

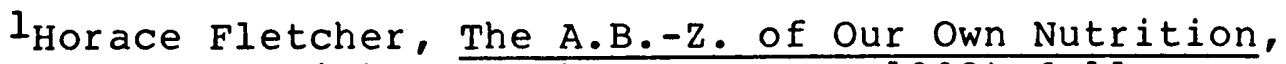
(New York: Frederick A. Stokes Company, 1903):6-11.

2 Deutsch, Nuts Among the Berries, pp. 111-112, 114 .

${ }^{3}$ William Banting, Letter on Corpulence, Addressed to the Public (London: Harrison and Sons, 1863).

${ }^{4}$ Robert C. Atkins, Dr. Atkins' Diet Revolution: The High Calorie Way to Stay Thin Forever. New York: David McKay, Inc., 1972.

${ }^{5}$ Deutsch, Nuts Among the Berries, pp. 219-220. 
quackery throughout the ages. ${ }^{1}$

These "devices" include the use of legends, testimonials and religion to appeal to the consumer's emotion. 2

\section{Current Theories of Weight Loss}

Many of the theories on weight reduction that are published in popular women's magazines are based on research that is controversial among the researchers. Periodic resurgents of interest in the low-carbohydrate diet have occurred ever since the "Banting Diet" first appeared. 3 The most notable of these diets include Dr. Atkins' Diet Revolution and The Doctor's Quick Weight Loss Diet by Stillman. ${ }^{4}$ Dr. Atkins, claims that carbohydrates are responsible for fattening people, that his diet induces production of "fat mobilizing hormone" (FMH) which helps the body "burn off its fat," and that over-eating on this diet can still result in weight loss

$1_{\text {William J. Darby, "The Unicron and Other Lessons }}$ from History," Nutrition Reviews 341 , supplement (July $1974): 57-61$.

2 Ibid.

${ }^{3}$ American Medical Association Council on Food and Nutrition, "A Critique of Low-Carbohydrate Ketogenic Weight Reduction Regimens," Journal of the American Medical Association 224 (June 4, 1973):1415.

${ }^{4}$ Atkins, Diet Revolution, pp. 141-238; Irwin Maxwell Stillman and Samm Sinclair Baker, The Doctor's Quick Weight Loss Diet (Englewood Cliffs, N.J.: Prentice-Hall, 1967; Dell Publishing Co., Inc., 1968), pp. $50-78$. 
as long as ketosis occurs. ${ }^{1}$ The stand of the American Medical Association against this diet is primarily based upon this last claim which violates the first law of thermodynamics regarding the equilibrium of energy within an isolated system, the high fat content of this diet and the impracticality of the diet for use in long-term weight reduction. 2 In contrast, a report by Miller and Mumford, in which the effect of both high and low-protein diets was tested on two, eight and six students in 1963, 1964, and 1965, respectively, held that a dietary imbalance of nutrients (carbohydrate, protein, and fat) made it possible to overeat without gaining weight. These authors ascribe their results to a resultant increase in heat production that occurs on a diet with an imbalance of nutrients. ${ }^{3}$ Several years later Kasper et al., reported only a slight weight gain in five normal subjects on high-fat, low-carbohydrate formula diets for forty-five days. A concomitant decrease in serum triglycerides was also reported.4 However, Pilkington et al., did not

$1_{\text {Atkins, }}$ Diet Revolution, pp. 1-20.

2A.M.A. Council, "Critique of Low-Carbohydrate Weight Reduction," pp. 1415-1419.

${ }^{3}$ D. S. Miller and Pamela Mumford, "Gluttony 1. An Experimental Study of Overeating on Low- or High-Protein Diets," American Journal of Clinical Nutrition 20 (November 1967):1212-1222.

${ }^{4} \mathrm{H}$. Kasper, H. Theil and M. Ehl, "Response of Body Weight to a Low-Carbohydrate, High-Fat Diet in Normal and Obese Subject," American Journal of Clinical Nutrition 26 (February 1973): $\overline{197-204}$. 
report finding any advantage of a low-carbohydrate diet over other diet regimens with respect to weight-loss, and Yudkin and Carey found that an eventual total decrease in caloric intake occurred with such a diet and resulted in weight-loss. ${ }^{l}$ In light of the claims of success with these diets the American Medical Association challenges:

If such diets are truly successful, why then, do they fade into obscurity within a relatively short period only to be resurrected some years later in a slightly different guise and under new sponsorship. Moreover, despite the claims of universal and painless successfor such diets, no nation-wide decrease in obesity has been reported. 2

This sentiment was echoed by Mayer in regard to the prevalence of many other diet fads and clinical fashions in the treatment of obesity. ${ }^{3}$

Starvation, semi-starvation and the protein-sparing modified fast (a calorically restricted ketogenic diet) regimens have been considered and studied by researchers and, occasionally, have been self-prescribed by the public. 4 Yang and Van Itallie studied the short-term

$1_{\text {T. R. E. Pilkington et al., "Diet and weight }}$ Reduction in the Obese," Lancet 1 (April 16, 1960):856-858; John Yudkin and Margaret Carey, "The Treatment of Obesity by the 'High-Fat' Diet. The Inevitability of Calories," Lancet 2 (October 29, $1960)$ : 939-941.

2A.M.A. Council, "Critique of Low-Carbohydrate Weight Reduction," p. 1415.

3Jean Mayer, "Reducing by Total Fasting," Human Nutrition: Its Medical and Social Aspects (Springfield, Ill.: Charles C. Thomas, 1972), p. 373.

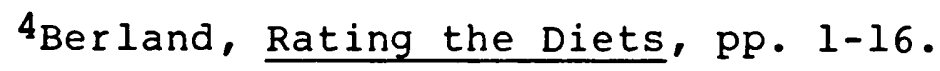


change in body composition after subjects had followed various diets. By supplying 800 kilocalories of energy on the semi-starvation and protein-sparing modified fast regimens they found that the rate of fat loss was not significantly affected by the composition of the diet and that water loss was responsible for the increased weightloss on the starvation and protein-sparing diets. ${ }^{1}$ Long-term follow-ups of fasting and semi-starvation regimens, conducted by Drenick and Johnson, and Sohar and Sneh, separately, showed poor success. 2 In addition, the protein-sparing modified fast, reported by Merrick to be successful in short-term weight loss with adolescents, still did not prevent loss of lean body mass in these patients. 3 In summary, the ketogenic regimens have shown no advantage over nonketogenic regimens in sparing body protein, while both the ketogenic and fasting regimens may result in the same metabolic side-effect of

$1_{\text {Mei-Uih Yang and Theodore B. Van Itallie, }}$ "Composition of Weight Lost During Short-term Weight Reduction," Journal of Clinical Investigation 58 (September 1976):727-730.

2 Ernest J. Drenick and Daisie Johnson, "Weight Reduction by Fasting and Semistarvation in Morbid Obesity: Long-term Follow-up," International Journal of Obesity 2 (1978):123-132; Ezra Sohar and Ephraim Sneh, "Follow-up of Obese Patients 14 Years After a Successful Reducing Diet," American Journal of Clinical Nutrition 26 (August 1973): 845-848.

$3_{\text {Russell J. Merritt, "Treatment of Pediatric and }}$ Adolescent Obesity," International Journal of Obesity 2 (1978): 207-214. 
nausea, fatigue and postural hypotension. ${ }^{1}$ Feinstein concluded that:

- . higher percentages of success might be obtained by less rigid devotion to concepts of diets, drugs, and devices and by more flexible attention to the total status of the dieting patient.2

This conclusion came after an appraisal of existing data on weight reduction showed no theory was clinically verifiable. ${ }^{3}$ Mayer also noted a lack of verification for theories of obesity and attributed the humerous of fad diets mainly to a lack of scientific knowledge of the cause, and therefore, the ultimate treatment for obesity. 4

Nutritional Knowledge of Consumers

A substantial amount of attention to the diets in popular women's magazines might not be warranted if the consumers who read the popular women's magazines were

$I_{\text {Theodore B. Van Itallie, "Diets for Weight }}$ Reduction: Mechanisms of Actionand Physiological Effects," International Journal of Obesity 2 (1978):119-121.

2 Alvan R. Feinstein, "The Treatment of Obesity: An Analysis of Methods, Results, and Factors which influence Success," Journal of Chronic Diseases, 11 (April 1960) : 349-393.

3 Ibid.

4 Jean Mayer, "Reducing by Total Fasting," Human Nutrition: Its Medical and Social Aspects (Springfield, Ill.: Charles C. Thomas, 1972), p. 373-378. 
believed to have a sizable knowledge base upon which to evaluate weight reduction advice in women's magazines. However, it has been demonstrated by several researches that the nutritional knowledge base demonstrated by women is limited. 1

Young et al. carried out one of the most extensive and frequently referred to studies on the nutritional knowledge of women. The level of nutritional knowledge of homeakers in Syracuse (315 households) and Rochester (331 households) was assessed by the number of food groups for which each homemaker could give a nutritionally correct reason for including that food group in the family meals. ${ }^{2}$ Based on this assessment 20-30 percent of the homemakers demonstrated at least a "minimal" level of nutritional knowledge (by being able to name three or four good reasons for including each food group in family

$I_{\text {Charlotte M. Young, Betty Greer Waldner and }}$ Kathleen Berresford, "What the Homemaker Knows About Nutrition. II. Level of Knowledge," Journal of The American Dietetic Association 32 (March 1956):218-222; Nancy E. Schwartz, "Nutritional Knowledge, Attitudes and Practices of High School Graduates," Journal of The American Dietetic Association 66 (January 1975):28-31; Ercel S. Eppright et al., "The North Central Regional Study of Diets of Preschool Children. Part 2. Nutritional Knowledge and Attitudes of Mothers," Journal of Home Economics 62 (May 1970):327-332.

${ }^{2}$ Charlotte M. Young, Betty Greer Waldner and Kathleen Berresford, "What the Homemaker Knows About Nutrition. I. Decription of Studies in Rochester and Syracuse, N.Y.," Journal of the American Dietetic Association 32 (March 19567):214-217; Young et al., "What the Homemaker Knows About Nutrition. II.," pp. 218-222. 
meals), but one-third to one-half of the participants were unable to demonstrate any evidence of nutritional knowledge. In a study of 313 female high school graduates; Schwartz found a higher level of knowledge to have beendemonstrated on general nutritional concepts than on other areas of nutrition such as the need for vitamins, food composition or the relationship of dietary fat to

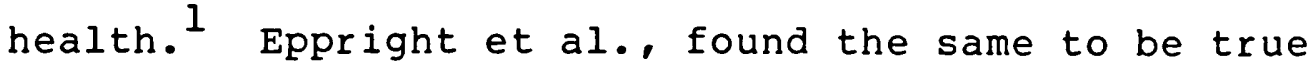
among mothers of pre-school children. ${ }^{2}$ Beliefs categorized as faddist by Jalso et al., were found to be common to older, and lower income, groups of both sexes. ${ }^{3}$ However, Wilson and Lamb have found that female college graduates were the largest group of participants accepting false beliefs about food. ${ }^{4}$

Schwartz reported that 71.2 percent of female high school respondents indicated magazines as a source of printed nutritional information. 5 This may be important

${ }^{1}$ Schwartz, "Nutritional Knowledge of High School Graduates," pp. 28-31.

2Eppright et al., "Part 2. Nutritional Knowledge and Attitudes of Mothers," pp. 327-332.

${ }^{3}$ Shirley B. Jalso, Marjorie M. Burns and Jerry M. Rivers, "Nutritional Beliefs and Practices," Journal of The American Dietetic Association 47 (October 1965) : 263-268.

${ }^{4}$ Mary Margaret Wilson and Mina W. Lamb, "Food Beliefs: Related to Ecological Factors in Women," Journal of Home Economics 60 (February 1968):115-118.

5 Schwartz, "Nutritional Knowledge of High School Graduates," pp. 28-31. 
since 38 percent of the respondents indicated they were on weight reducing diets. A general conclusion that sources other than high school home economics courses contributed to the nutritional knowledge and attitudes of women towards nutrition was reached as a result of this study. Magazines were also mentioned most frequently as a source of nutritional information by the homemakers in a study reported by young et al. ${ }^{l}$ In addition, magazines and newspapers were the most frequent sources of information mentioned by "faddists" and "non-faddists" of both sexes according to Jalso et al. ${ }^{2}$

While the nutritional knowledge of consumers has been demonstrated to be limited in the aforementioned studies, others have emphasized the advantage of knowledgeable consumers. ${ }^{3}$ While Preston expressed a preference for "intelligent selective" consumers over distrusting consumers, Brown and Dimsdale acknowledged that the value of knowledgeable consumers lies in making businesses more

${ }^{1}$ Charlotte M. Young, Betty Greer Waldner and Kathleen Berresford, "What the Homemaker Knows About Nutrition. IV. Her Food Problems, Shopping Habits and Sources of Information," Journal of The American Dietetic Association 32 (May 1956):429-434.

2Jalso et al., "Nutritional Beliefs," pp. 263-268.

${ }^{3}$ Ivan L. Preston, "Observations on Consumer's Use of the Mass Media," The Journal of Consumer Affairs 3 (Summer 1969):59-72, Stephen W. Brown and Parks B. Dimsdale, "Consumer Information: Toward an Approach for Effective Knowledge Dissemination," The Journal of Consumer Affairs 7 (Summer 1973):55-60. 
responsive to the true needs of their customers. ${ }^{1}$

Certain research findings have demonstrated that consumers do gain knowledge from information published for their benefit. A positive relationhip between increased levels of information and consumer puchase preferences has been demonstrated by stanley and sproles et al., separately. ${ }^{2}$ stanley found that subjects who were given articles from Consumer Reports 1975, which discussed and evaluated popular breakfast cereals, were significantly influenced in their nutritional evaluation and overall preferences of actual breakfast cereals. ${ }^{3}$ sproles et al., also found that with increased levels of information there is an increase in the efficiency of consumer perception of product quality and purchase preferences. 4 The value of consumer education expressed by Preston in the following statement:

Education of the consumer in the intelligent selective use of the mass media is sounder than telling him to

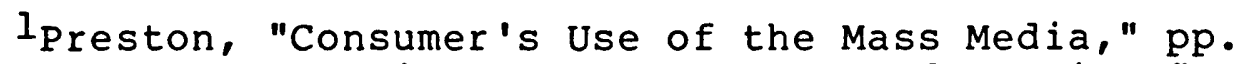
59-72; Brown and Dimsdale, "Consumer Information," pp. $55-60$.

2 Thomas J. Stanley, "Nutritional Information and Preferences for Breakfast Cereals," The Journal of Consumer Affairs 11 (Winter 1977):12 1-126; George B. Sproles, Boren Geistfeld and Suzanne B. Badenhop, "Informational Inputs as Influences on Efficient Consumer Decision-Making," The Journal of Consumer Affairs 12 (Summer 1978):88-103.

${ }^{3}$ Stanley, "Nutritional Information," pp. 121-126.

${ }^{4}$ sproles et al., "Influences on Efficient Consumer Decision-Making," pp. 88-103. 

avoid and distrust information acquired through the
media. 1

The interest in an objective instrument for the evaluation of weight reduction advice is stimulated by the above statement. The criticism illicited by the weight reduction articles, and the limited knowledge base demonstrated among women who might read these articles, also indicate the necessity of developing a dependable tool, which will provide meaningful evaluatipns of nutritional information to professionals in diet and nutrition. This would enable the professional to bring more reliable information to the consumers.

The Rating Scale as a Method

of Evaluation

While measurement refers to careful observation of performance under standard conditions, evaluation involves the use of measurement to make a value judgement. ${ }^{2}$ In developing an evaluative process issues of validity, reliability and relevance need consideration. ${ }^{3}$ 59-72.

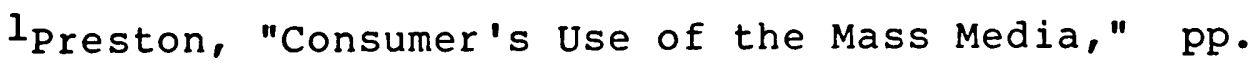

2 Georgia Sachs Adams, Measurement and Evaluation in Education, Psychology and Guidance (New York: Holt, Rinehart and Winston, 1966), pp. 1-16.

3 Adams, Measurement and Evaluation, pp. 103-148; Stephen Isaac and William B. Michael, Handbook in Research and Evaluation, (San Diego: Robert R. Knapp, 1971), p. 87; Thomas D. Cook, Fay Lomax Cook and Melvin M. Mark, 
Validity, especially content validity, is a subjective measure since it is concerned with how well a test sample represents theuniverse of criterion behavior. For the most part, the measure of validity depends on that of reliability. ${ }^{l}$

Choice of format can play a large role in avoiding sources of error. The five-point rating scale has been favored for use in the evaluation of clinical performance and behavorial competencies of dietetics students. ${ }^{2}$ However, this scale is not ideal where the central tendency error is a concern. ${ }^{3}$ on the other hand the forced-choice format has been found to be unacceptable because it attempts to trick the rater, and therefore,

"Randomized and Quasi-Experimental Designs in Evaluation Research: An Introduction," in Evaluation Research Methods, ed. Leonard Rutman, (Beverly Hills: Sages Publications, Inc., 1977), pp. 103-139; Hans B. Thorelli and Sarah V. Thorelli, Consumer Information Systems and Consumer Policy, (Cambridge, MA: Ballinger Publishing Company, 1977), pp. 77-111.

${ }^{1}$ Isaac and Michael, Handbook in Research, p. 87 ; Adams, Measurement and Evaluation, pp. 102-148.

2 Susan Phillips Himburg, "The Identification and Evaluation of Proposed Minimum Competencies for the Dietetic Technician in Patient Interviewing and Diet Counseling," (Ph.D. dissertation, University of Miami, 1979), pp. 144-147; Clair Agriesti Johnson and Roberta S. Hurley, Design and Use of an Instrument to Evaluate Students' Clinical Performance," Journal of The American Dietetic Association 68 (May 1976):450-453; Joyce B. Tower and Paula M. Vosburgh, "I. Theoretical Considerations and Method of Construction. Development of a Rating Scale to Measure Learning in Clinical Dietetics," Journal of The American Dietetic Association 68 (May 1976):440-445.

${ }^{3}$ Isaac and Michael, Handbook in Research, p. 58. 
encourages deliberate faking. ${ }^{1}$ Remmers discussed the various formats for rating scales under the general classifications of numerical, graphic, cumulated-points, check lists, and forced-choice rating scales. ${ }^{2}$ The basic classifications are best described as follows:

Numerical rating-scales - in general, have numbers assigned to categories, usually on an a priori basis. Graphic rating scales - provide a continuous straight line with cues or categories along the line to guide the rater.

Cumulated-points rating scale - a method of scoring common to several rating scale types, by which scales are scored similar to psychological tests, usually one or zero per item.

Check lists - a list of items to be checked, or numbered, according to their occurrence.

Forced-choice rating scales - psychologically scaled instrument where the rater is forced to choose the best liked and least liked members of a set of items. 3

Based on an account of various types of numerical scales, Remmers concluded that the scales are "easy to construct and apply." 4 He did, however, provide a number of suggestions to minimize sources of error in the

lpatricia Cain Smith and L. M. Kendall, "Retranslation of Expectations: An Approach to the Construction of Unambiguous Anchors for Rating Scales," Journal of Applied Psychology 47 (April 1963):148-155.

2H. H. Remmers, "Chapter 7. Rating Methods in Research on Teaching, " in Handbook of Research on Teaching, ed. N. L. Gage, (Chicago: Rand McNally \& Company, 1963), pp. 331-343.

3 Ibid.

4Ibid., pp. 331-339. 
construction of graphic rating scales. A few of them are as follows:

1. The line, whether horizontal or vertical, should be unbroken.

2. The line should be five or six inches long--long enough to allow indication of all the discrimination of which the reater is capable.

3. The direction of lines should be the same; i.e., the socially desirable end should be the same for all the traits or other objects to be rated.

4. If several objects are to be rated the arrangement on the page that favors rating all of them on one characteristic is best.

5. Descriptive categories should be as near as possible to the points of the scale they describe.

6. The categories need not be equally spaced.l It should be noted that some of these suggestions may still be questionable according to Remmers himself.

\section{Summary}

The proliferation of weight reduction regimens and advice in popular women's magazines parallels the proliferance of weight reduction regimens found througout the mass media. Perhaps inspired by an increased concern for the health risks attributed to obesity, consumers are believed to be spending huge amount of money for weight reduction. Because the articles on weight reduction advice in popular women's magazines may fail to encourage

$1_{\mathrm{H}}$. H. Remmers, "Chapter 7. Rating Methods in Research on Teaching, " in Handbook of Research on Teaching, ed. N. L. Gage, (Chicago: Rand McNally \& Company, 1963), pp. 335-339. 
balanced caloric deficits and may also fail to correct faulty food habits, they have been criticized as faddist by some professionals. There is lack of consensus among professionals and researchers as to what causes obesity. In addition, a lack of consensus over what can be used to treat obesity successfully may also be partly responsible for the proliferance of weight reduction schemes offered to the consumer. Concern with the validity of weight reduction advice found in popular womens' magazines is increased by the level of consumer knowledge of nutrition which has been demonstrated to be a basic level at most. It is believed that consumers do benefit from consumer education programs and information. In order to bring information on the validity of weight reduction advice in popular women's magazines to consumers, nutrition experts themselves need an objective, reliable instrument which can be used to evaluate the weight reduction advice in those same magazines. 
CHAPTER III

METHODOLOGY

Introduction

This study was carried out in three parts. The first part consisted of a Field Test, in which nine reactors completed, two Article Evaluation forms on two articles from popular women's magazines and an Instrument Evaluation form. In the second part a validity study was carried out by having Instrument Evaluation forms completed by 30 experts throughout the United States and Canada. A Reliability Study, made up the third part, and consisted of having three raters rate the same eight articles from popular women's magazines using the Article Evaluation form.

\section{$\underline{\text { Field Test }}$}

The field test was designed to answer the question: What characteristics would experts agree should be part of an instrument used to evaluate articles on weight reduction advice?

Selection of the Reactors. The reactors were solicited by asking the department chairmen of three state 
universities in Florida, with programs in Food and Nutrition and/or Dietetics, to distribute three evaluation packets among their staff. Each packet contained two articles from popular women's magazines, two Article Evaluation forms and one Instrument Evaluation form.

Development of the Instrument. The characteristics of a faddist weight reduction article were derived from the various critiques of these regimens in the literature. See Appendix A. The reactors were asked to read two articles from popular women's magazines and fill out an Article Evaluation form (the instrument) for each article. The instrument required that they rate the extent to which each characteristic appeared or existed in the article being evaluated For each of the ten characteristics, a choice of one of four answers was possible. The choices on the rating scale were as follows: 1) characteristic exists to a large extent; 2) characteristic exists to some extent; 3) characteristic exists to a small extent; 4) characteristic does not exist. The four-point scale was selected to avoid the faking encouraged by the forcedchoice format and the central tendency error that may accompany a five-point scale.

The reactors were also asked to fill out an Instrument Evaluation form which required that each expert rate the importance of each characteristic on a four-point scale. This scale was similar to the one used in the Article Evaluation with the intervals being labeled as 
follows: 1) very important; 2) somewhat important; 3) slightly important; 4) not important. In addition to this, space was allowed for the experts to add characteristics they thought should be included in this instrument. Selection of the Articles. The 1979 issues of two popular women's magazines were obtained and reviewed for articles containing weight reduction regimens or advice which met the established criteria for a weight reduction article. That is, an article in a popular women's magazine which contained a diet/menu plan and/or information on obesity and overweight and/or advice for following a diet plan. The eight articles were then numbered and two were selected at random and sent to the reactors.

\section{Validity study}

This part of the study was designed to determine the validity of an instrument used to evaluate articles on weight reduction advice.

Selection of the Experts. A list of all professionals who had published an article in the 1979 issues of the American Journal of Clinical Nutrition, the Journal of The American Dietetic Association or the Journal of Nutrition Education was compiled. Thirty experts were selected at random from this list.

Revision of the Instrument. Based on the results of the Field Test, the Instrument Evaluation form was revised. Each expert was sent a revised copy of the 
Instrument Evaluation Form that asked them to rate the importance of each characteristic. See Appendix B. The experts were also asked to suggest other characteristics they thought were important in rating an article on weight reduction advice from a popular women's magazine. Space for comment on each characteristic was provided. In addition, demographic data was obtained on each expert. This was accomplished with questions designed to ascertain the state in which the institution was located, whether the institution was public or private, the size of the institution, and the number of years each of the experts had practiced in the field of nutrition.

Replies. Replies were compiled and tabulated.

\section{Reliability Study}

The third part of the study was designed to determine the degree of consistency among raters using this scale to evaluate weight reduction articles from popular women's magazines.

Selection of the Raters. For this part of the study, Registered Dietitians with Master of Science degrees were used as raters. Three raters were selected from the population of local dietitians, and agreed to participate in the study.

Revision of the Instrument. The Article Evaluation form was revised according to the results and suggestions of the Field Study. See Appendix C. Space for comment on 
each characteristic was provided next to each characteristic.

Introduction of the Instrument to the Raters. Before the instrument was distributed to the raters, a training session on how to use the instrument was held. All of the raters came to the meeting. During this session each rater was asked to evaluate a weight reduction article from a popular women's magazine. The results of evaluating the article were compiled and discussed at this meeting so that the meaning of each characteristic became clearer to the raters. At the end of the session the raters were given the eight articles with their accompanying evaluation forms and were asked to evaluate no more than two articles per day. This last request was to insure that the raters would not become fatigued from completing too many evaluations at once and therefore decrease the reliability of the instrument.

Selection of Articles. All articles (8) published in 1979 on weight reduction from two popular women's magazines were submitted to the raters for evaluation.

Analysis of Data. The data was analyzed using the Friedman Two-way Analysis of Variance; the formula for this is as follows:

$$
X_{r}^{2}=\frac{12}{N k(k+1)}\left[\sum R_{i}^{2}\right]-3 N(k+1)
$$

where $k=$ number of columns, $N=$ number of rows, $\sum_{1}^{2}=$ sum of the squared rank sums, and $d f=k-1$. 
CHAPTER IV

\section{RESULTS AND DISCUSSION}

\section{Field Test}

This part of the study was designed for the purpose of determining what characteristics experts would agree should be part of an instrument used to evaluate articles on weight reduction advice.

Out of the nine evaluation packets sent out, seven were completed and returned. In using the Article Evaluation form, some characteristics were evaluated with closer agreement than others, while two of the characteristics were not understood by a few of the reactors. Each of the characteristics on the Instrument Evaluation were found to be at least somewhat important by the majority of the reactors. Several of the reactors had difficulty understanding and rating item two which consisted of, "May, possibly, produce ill side-effects." In addition, item eleven, "To what extent to do you feel this scale is important?" was apparently difficult to rate. The additional characteristics that were suggested by the reactors were, for the most part, some form of what was intended in the original characteristics. Because of 
this, it was decided to illustrate all of the characteristics with examples and to use several of the suggested characteristics as the examples. Three of the characteristics suggested by the reactors were added to the instrument for the validity and reliability studies.

\section{Validity study}

This part of the study was designed to determine the validity of an instrument designed to evaluate articles on weight reduction.

Thirty Instrument Evaluation forms were sent out to the experts, ten were returned, and of these six rated the importance of each characteristic. The demographic data showed that two experts were from New York, while Texas, Rhode Island, Maryland and Quebec were each represented by one expert. Two of the experts worked at public institutions, three of them worked a private institutions and one was in private practice as a consultant. Three of the experts were associated with institutions that had more than 3,000 students/patients and/or employees, while one was associated with an institution of less than 300 and one was with an institution with between 300 and 600 people. Four experts had been practicing in their field 10 to 21 years, while one had been practicing less than 10 years, and another had been practicing 21 to 30 years. The composite ratings of the items are shown in Table 1. The first characteristic, "Emphasizes specific food or 
Table 1: Composite Ratings of Experts

on the Instrument Evaluation

\begin{tabular}{llcc}
\hline & some- & & \\
very & what & slightly not \\
impt. & impt. & impt. impt.
\end{tabular}

\begin{tabular}{|c|c|c|c|c|c|}
\hline 1 & $\begin{array}{l}\text { Emphasizes specific foods or } \\
\text { foods that may not normally } \\
\text { be consumed. }\end{array}$ & 1 & 3 & 2 & 0 \\
\hline 2. & $\begin{array}{l}\text { May, possibly, produce } \\
\text { ill side-effects. }\end{array}$ & 5 & 10 & 1 & 0 \\
\hline 3. & $\begin{array}{l}\text { Is glowingly promoted, } \\
\text { ensuring a lack of } \\
\text { deprivation. }\end{array}$ & 2 & 3 & 0 & 1 \\
\hline & $\begin{array}{l}\text { Is based on questionable } \\
\text { biochemical theories. }\end{array}$ & 5 & 0 & 0 & 1 \\
\hline & $\begin{array}{l}\text { Uses testimonials in place } \\
\text { of documented research. }\end{array}$ & 2 & 3 & 1 & 0 \\
\hline & $\begin{array}{l}\text { Claims a new revolutionary } \\
\text { idea. }\end{array}$ & 4 & 0 & 1 & 1 \\
\hline 7. & $\begin{array}{l}\text { Claims an unusually high } \\
\text { rate of success. }\end{array}$ & 3 & 2 & 1 & 0 \\
\hline & $\begin{array}{l}\text { Claims persecution by } \\
\text { the medical profession. }\end{array}$ & 3 & 1 & 0 & 2 \\
\hline & $\begin{array}{l}\text { Is based on premature } \\
\text { conclusions from } \\
\text { scientific data. }\end{array}$ & 4 & 1 & 0 & 1 \\
\hline 10 & $\begin{array}{l}\text { Fails to encourage develop- } \\
\text { ment of new eating habits. }\end{array}$ & 5 & 1 & 0 & 0 \\
\hline 11. & $\begin{array}{l}\text { Uses a negative psychological } \\
\text { approach. }\end{array}$ & 2 & 3 & 1 & 0 \\
\hline 12. & $\begin{array}{l}\text { Includes questionable state- } \\
\text { ments or half-truths. }\end{array}$ & 4 & 1 & 0 & 1 \\
\hline 13. & $\begin{array}{l}\text { Fails to give enough infor- } \\
\text { mation to follow diet } \\
\text { properly. }\end{array}$ & 4 & 2 & 0 & 0 \\
\hline
\end{tabular}


food that may not normally be consumed," was rated very important by one expert, somewhat important by three experts and slightly important by two experts. The second characteristic, "May produce ill side-effects," was found to be very important by five experts and slightly important by one expert. Characteristic number three, "Is glowingly promoted as a quick and easy solution to a diet problem," was found to be very important by two experts, somewhat important by three experts and not important by one expert. Five experts found the fourth characteristic, "Is based on questionable biochemical theories," to be very important while one expert thought this characteristic was not important. The fifth characteristic, "Uses testimonials in place of documented research," was found to be very important by two experts, somewhat important by three experts and slightly important by one expert. Characteristic number six, "Claims a new revolutionary idea," was found to be very important by four experts, slightly important by one expert and not important by another expert.

The seventh characteristic, "Claims an unusually high rate of success," was found to be very important by three experts, somewhat important by two experts and slightly important by one expert. The eighth characteristic, "Claims persecution by the medical profession," was found to be very important by three experts, somewhat important 
by one expert and not imprtant by two experts. Characteristic number nine, "Is based on premature or faulty conclusions from scientific data," as found to be very important by four experts, somewhat important by one expert and not important by another expert. Five experts thought that the tenth characteristic, "Fails to encourage development of new eating habits," was very important, while one expert thought it was somewhat important. The eleventh characteristic, "Uses a negative psychological approach," was found to be very important by two experts, somewhat important by three experts, and sightly important by one expert. Characteristic number twelve, "Includes questionable statements or half-truths," was found to be very important by four experts, somewhat important by one expert and not important by another expert. The last characteristic, "Fails to give enough information to follow diet properly," was found to be very important by four experts and somewhat important by two experts.

with regard to the demographic variations in ratings, the average validity rating obtained from each expert, by state, was as follows:

$\begin{array}{ll}\text { Texas Island } & 1.08 \\ \text { Rhode In } & 1.31 \\ \text { Maryland } & 1.31 \\ \text { New York } & \\ \quad \text { a } & 1.36 \\ \text { b } & 3.15 \\ \text { Quebec } & 2.00\end{array}$


While an "average validity rating" is not an accurate indication of the validity of this instrument, it is useful in analyzing the tendencies of the experts in rating the importance of the thirteen characteristics. An average validity rating of 1.36 or lower, obtained from the experts from Texas, Rhode Island, Maryland, and New York (1), indicated that the instrument was either somewhat or very important. The average validity rating of 2.00 , obtained from the expert from Quebec, indicates that the instrument was somewhat important. The lowest average rating of 3.15 , obtained from the second expert from New York (b), indicated that the instrument was slightly important.

There was no apparent correlation between the average validity rating of the 13 characteristics and the location for the institution with which the experts were affiliated. The same held true for the type of institution (i.e. public or private), and the number of years the experts had been practicing in their fields.

There was, however, some correlation of opinion between the average validity rating of the instrument with regard to the size of the instituion with which the experts were associated. The experts associated with institutions of less than 300 students/patients and/or employees gave the instrument average validity ratings of 2.00 and 3.15. Three experts associated with institutions with more than 3,000 students/patients and/or employees 
gave the instrument average validity ratings of $1.36,1.31$ and 1.31. There was one expert associated with an institution of 300-600 persons that gave the instrument an averate rating of 1.08 .

The 20 percent rate of return in this section of the study precluded the use of advanced statistical analysis, but, as Table 1 indicates, none of the characteristics were judged absolutely invalid. On the contrary, the majority of the experts found each characteristic to be very or somewhat important in evaluating an instrument that is to be used in analyzing weight reduction articles in women's magazines.

\section{Reliability Study}

This part of the study was designed to determine the degree of consistency among raters using this scale to evaluate weight reduction articles from popular women's magazines. The mean ranks and chi-square values for each of the 13 characteristics across eight articles are present in Table 2. These values were computed using the Friedman Two-way Analysis of Variance (ANOVA). Table 2 also indicates the level at which the chi-square values indicate a significance difference among the raters. Since the null hypothesis was desirable in this study, a more liberal level of significance (.10) was selected to avoid the Type II error of failing to reject a false null 
Table 2: Results of Friedman Two-Way Analysis of Variance

$\mathrm{df}=2$

\begin{tabular}{|c|c|c|c|c|c|}
\hline \multirow{2}{*}{$\begin{array}{l}\text { Charac- } \\
\text { teristic }\end{array}$} & \multicolumn{3}{|c|}{$\begin{array}{l}\text { Mean Ranks } \\
\text { for Raters }\end{array}$} & \multirow{2}{*}{$\begin{array}{l}\text { Chi- } \\
\text { Square }\end{array}$} & \multirow{2}{*}{$\begin{array}{c}\text { Probability } \\
\text { Level }\end{array}$} \\
\hline & 1 & 2 & 3 & & \\
\hline 1 & 1.81 & 2.19 & 2.00 & .563 & .755 \\
\hline 2 & 1.88 & 2.37 & 1.75 & 1.750 & .417 \\
\hline 3 & 2.19 & 2.12 & 1.69 & 1.187 & .552 \\
\hline 4 & 2.16 & 2.44 & 1.50 & 3.562 & .168 \\
\hline 5 & 1.88 & 2.00 & 2.12 & .250 & .882 \\
\hline 6 & 1.81 & 2.44 & 1.75 & 2.312 & .315 \\
\hline 7 & 1.81 & 2.50 & 1.69 & 3.062 & .216 \\
\hline 8 & 2.06 & 2.06 & 1.88 & .188 & .911 \\
\hline 9 & 2.19 & 2.31 & 1.50 & 3.062 & .216 \\
\hline 10 & 2.44 & 2.00 & 1.56 & 3.062 & .216 \\
\hline 11 & 2.19 & 1.75 & 2.06 & .813 & .666 \\
\hline 12 & 2.31 & 2.31 & 1.37 & 4.688 & .096 \\
\hline 13 & 2.00 & 2.12 & 1.88 & .250 & .882 \\
\hline
\end{tabular}

Formula:

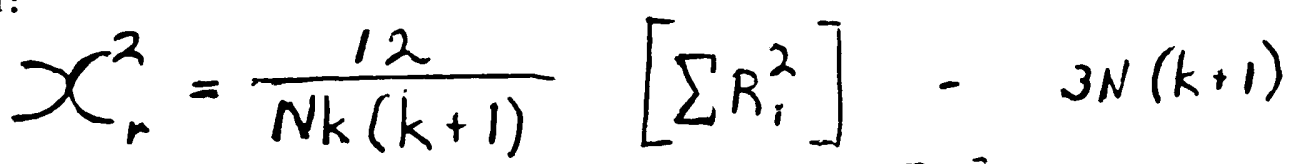

where $k=$ number of columns, $N$ - number of rows, $\sum R_{i}^{2}=$ sum of the squared rank sums, and $\mathrm{df}=\mathrm{k}-1$. 
hypothesis. It is important to note that a nonsignificant finding is desirable in this study.

There was no statistically significant difference at the .10 level $(d f=2)$ for the raters on all but the twelfth characteristic. In addition, for all but the twelfth characteristic, the Friedman Test resulted in chi-square values below the critical value of 4.60 needed to show a significant difference. The twelfth characteristic rated the articles as to whether each "Includes questionable statements or half-truths." The same mean rank of 2.31 was obtained from raters 1 and 2 on the twelfth characteristic, but a mean rank of 1.37 for the third rater resulted in the high chi-square value that was high enough to indicate a significant difference.

The remaining characteristics upon which the articles were rated resulted in chi-square values ranging from .188 to 3.562 , these values in turn ranged from the .911 level to the .168 level of probability. This is shown in Table 3, which lists the characteristics according to their chi-square values.

The characteristic which asked the raters to evaluate whether each article "Includes questionable statements or half-truths," was the only one found to be significantly different in ratings at the .10 level $(d f=2)$. Since this item required the raters to decipher "shades" of truth from fallacy throughout the articles, the difficulty in obtaining agreement here can be appreciated. Regardless 
Characteristic

Claims persecution by the

medical profession. (8)

Uses testimonials in place

of documented research. (5)

Chi-Square

.188

.911

Fails to give enough information to follow diet

properly. (13)

Emphasizes specific foods

or foods that may not

normally be consumed.

Uses a negative psycho-

logical approach. (11)

Is glowingly promoted as

a quick and easy solution

to a diet problem. (3)

1.187

.552

May produce ill side-

effects. (2)

1.750

Claims a new revolutionary

idea. (6)

2.312

Claims an unusually high

rate of success.

3.062

Is based on premature or

faulty conclusions from

scientific data. (9)

3.062

.216

Fails to encourage

development of new

eating habits. (10)

3.062

.216

Is based on questionable

biochemical theories. (4)

3.562

.168

Include questionable

statements or half-truths.

(12)

4.688

.096

* A probability level of .10 indicated an acceptable level of rater consistency at 2 degrees of freedom. 
of this, the rating scale produced a high degree of reliability as evidenced by the levels of significance for the chi-square values listed in Table 2. As might be expected the more technical or scientifically based characteristics had lower levels of significance and higher chi-square values, as shown in Table 3 . 


\section{CHAPTER V}

SUMMARY, AND CONCLUSIONS AND RECOMMENDATIONS

\section{Summary}

The purpose of this study was to develop an instrument that could be used by experts to evaluate weight reduction advice in popular women's magazines. This was done in three parts. In the Field Test, the Instrument was constructed to determine what characteristics should be part of an instrument used to evaluate articles on weight reduction advice. This was accomplished by sending two articles from popular women's magazines, two Article Evaluation forms (instruments), and two Instrument Evaluation forms to nine reactors. With the seven evaluation packets that were completed and returned, it was possible to identify weaknesses in the items on the evaluation forms and make revisions.

The Validity Study was designed to determine the content validity of the instrument when used to evaluate articles on weight reduction. This was accomplished by sending the instrument evaluation form to thirty experts in the United States and Canada. The evaluation form entitled "Validity of an Instrument for Evaluating Articles on Weight control," was returned by ten experts 
and six of these had rated the thirteen characteristics. This was a 20 percent rate of return. Each of the thirteen characteristics was found to be valid (i.e., somewhat or very important) by the majority of the experts. A correlation of opinion with regard to the size of the institution with which the experts were associated. That is, the experts from small institutions tended to give lower average validity ratings for the instrument as a whole, while the experts from the largest institutions gave the instrument higher overall ratings.

The Reliability study sought to determine the degree of consistency among raters using this scale to evaluate weight reduction articles from popular women's magazines. Three raters were asked to evaluate eight articles from popular women's magazines on thirteen characteristics which made up the instrument. Using a Friedman Two-way Analysis of Variance (ANOVA), it was found that except for the twelfth item there was no significant difference between raters at the .10 level $(\mathrm{df}=2)$.

Conclusions

From the Field Test, it was concluded that each characteristic would be more easily understood when illustrated by examples. The results of the validity 
Study made it possible to conclude that the instrument was valid. From the Reliability study, it was concluded that the instrument was reliable.

\section{$\underline{\text { Recommendations }}$}

1. Further study on the validity of an instrument designed to evaluate weight reduction advice in women's magazines using only nutrition education experts is needed.

2. A repetition of the Reliability Study needs to be conducted using a larger number of raters and a larger number of articles for evaluation.

3. Further study on developing an instrument to evaluate weight reduction advice in women's magazines should also seek to evaluate positive characeristics rather than negative characteristics in these articles. 
APPENDIX 


\section{Article Evaluation}

Please enter a check under the column which best ciescribes your opinion of how well each of the following characteristics applies to this articles. The choice of answers is as follows:
1
2
3
4

characteristic

exists to a

large extent characteristic

exists to

some extent characteristic

exists to a

small extent characteristic does not

exist

$\begin{array}{llll}1 & 2 & 3 & 4\end{array}$

\footnotetext{
1. Emphasizes specific foods

or foods that may not normally

be consumed.

2. May, possibly, produce

ill side-effects.

3. Is glowingly promoted, ensuring a lack of deprivation.

4. Is based on questionable biochemical theories.

5. Uses testimonials in place of documented research.

6. Claims a new revolutionary idea.

7. Claims $100 \%$ success.

8. Claims persecution by the medical profession.

9. Is based on premature conslusions from scientific data.

10. Fails to encourage development of new eating habits.
} 


\section{APPENDIX B \\ Validity of an Instrument for Evaluating \\ Articles on Weight Control}

Please rate the extent to which you feel each of these eleven characteristics is important in rating an article on weight control by checking one of the four boxes to the right of that characteristic. If there are any additional characteristics which you feel should be included in this list, please add them in the spaces provided on the next page and rate their importance.

\begin{tabular}{cccc}
1 & 2 & 3 & 4 \\
\hline $\begin{array}{c}\text { very } \\
\text { important }\end{array}$ & $\begin{array}{l}\text { somewhat } \\
\text { important }\end{array}$ & $\begin{array}{l}\text { slightly } \\
\text { important }\end{array}$ & $\begin{array}{c}\text { not } \\
\text { important }\end{array}$
\end{tabular}

12234 Make any comments here.

\footnotetext{
2. May produce ill sideeffects. (e.g. Dizziness, anemia.)
}

\section{Is glowingly promoted as a quick and easy solution to a diet problem. (e.g. Promises very rapid weight loss.)
4. Is based on ques- tionable biochemi- cal theories. (e.g. Claims calories dont count.)

5. Uses testimonials in place of documented research. (e.g. Assures that advice is proclaimed by nutritionists.) 
12234 Make any comments here.

\begin{tabular}{|c|c|}
\hline 6. & $\begin{array}{l}\text { Claims a new revolu- } \\
\text { tionary idea. (e.g. } \\
\text { claims that the diet } \\
\text { is vastly different } \\
\text { from any other diet } \\
\text { that is known.) }\end{array}$ \\
\hline 7 & $\begin{array}{l}\text { Claims an unusually } \\
\text { high rate of success. } \\
\text { (e.g. claims that } \\
\text { everyone can succeed } \\
\text { by following this } \\
\text { advice.) }\end{array}$ \\
\hline 8. & $\begin{array}{l}\text { Claims persecution } \\
\text { by the medical pro- } \\
\text { fession. (e.g. } \\
\text { ". - but the med- } \\
\text { ical profession had } \\
\text { always ridiculed my } \\
\text { theories.") }\end{array}$ \\
\hline & $\begin{array}{l}\text { Is based on premature } \\
\text { or faulty conclusions } \\
\text { from scientific data. } \\
\text { (e.g. "The need for a } \\
\text { reduction in carbo- } \\
\text { hydrate intake is } \\
\text { supported by recent } \\
\text { studies attributing } \\
\text { serious arterial } \\
\text { damage to years of } \\
\text { eating refined car- } \\
\text { bohydrates and } \\
\text { genetic factors.") }\end{array}$ \\
\hline 10 & $\begin{array}{l}\text { Fails to encourage } \\
\text { development of new } \\
\text { eating habits. (e.g. } \\
\text { Crash dieting.) }\end{array}$ \\
\hline 11. & $\begin{array}{l}\text { Uses a negative psy- } \\
\text { chological approach. } \\
\text { (e.g. Refers to } \\
\text { people as pigs.) }\end{array}$ \\
\hline
\end{tabular}


12. Includes question-

12234 Make any comments here. able statements or half-truths. (e.g. "A vegetarian diet is low in fat because it contains no meat," is not always true with the use of high-fat cheeses and nuts.)

13. Fails to give enough information to follow diet properly. (e.g. Recommends a vegetarian diet with adequate protein but doesn't explain complementary proteins.)

14 .

15 .

16 .

17 .

Please answer the following questions.

1. In what state is your institution located?

2. Is your instituion public or private?

3. How many students/patients/ and/or employees does your institution have?

less than $300 \_300-600 \_601-1000 \_1001-3000$

Over 3000 
4. How many years have you been practicing in your field?

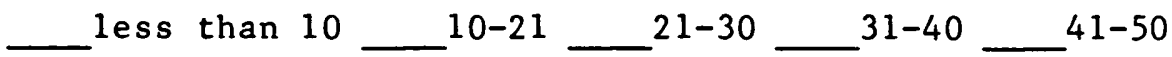

Over 50 .

Remarks : 


\section{Article Evaluation}

Please enter a check under the column which best describes your opinion of the extent to which each of the following characteristics occurs in this article. The choice of answers is as follows:
1
2
3
4

characteristic

exists to a

large extent

\author{
characteristic \\ exists to \\ some extent
}
characteristic exists to a
small extent

characteristic does not

exist

12234 Make any comments here.

\section{May produce ill side- effects. (e.g. Dizzi- ness, anemia.)}

3. Is glowingly promoted as a quick and easy solution to a diet problem. (e.g. Promises very rapid weight loss.)

4. Is based on questionable biochemical theories. (e.g. Claims calories don't count.)

5. Uses testimonials in place of documented research. (e.g. Assures that advice is proclaimed by nutritionists.)

6. Claims a new revolutionary idea. (e.g. Claims that the diet is vastly different from any other diet that is known.) 
$\begin{array}{lllll}1 & 2 & 3 & 4 & \text { Make any comments here. }\end{array}$

8. Claims persecution by the medical profession. (e.g. ". . . but the medical profession has always ridiculed my theories.")

9. Is based on premature

or faulty conclusions from scientific data. (e.g. "The need for a reduction in carbohydrate intake is supported by recent studies attributing serious arterial damage to years of eating refined carbohydrates and genetic factors."

10. Fails to encourage development of new eating habits. (e.g. Crash dieting.)

11. Uses a negative psychological approach. (e.g. Refers to people as Pigs.)

12. Includes questionable statements of halftruths. (e.g. "A vegetarian diet is low in fat," is not always true with the use of high-fat cheeses and nuts. 
$\begin{array}{lllll}1 & 2 & 3 & 4 & \text { Make any comments here. }\end{array}$

13. Fails to give enough information to follow the diet properly.

(e.g. Recommends a vege-

tarian diet with adequate

protein but doesn't ex-

plain complementary

proteins.)

Remarks: 


\section{SELECTED REFERENCES}

Abrams, H. Leon. "The Relevance of Paleolithic Diet in Determining Contemporary Nutritional Needs." Journal of Applied Nutrition 31 (June 1979):43-59.

Adams, Georgia Sachs. Measurement and Evaluation in Education, Psychology, and Guidance. New York: Holt, Rinehart and Winston, 1966.

American Home Economics Association A Guide for Evaluating Consumer Education Programs and Materials. Washington, D.C., 1972 .

American Medical Association. "A Critique of LowCarbohydrate Ketogenic Weight Reduction Regimens." The Journal of the American Medical Association 224 (June 4, 1973):1415-1419.

Atkins, Robert C. Dr. Atkins' Diet Revolution: The High Calorie way to Stay Thin Forever. New York: David McKay, Inc., 1972.

Baker, Ruth and Brumback, C. L. "Public Health and the Practicing Physician - Partners in Community Nutrition." Journal of the Florida Medical Association 66 (April 1979):457-462.

Banting, William. Letter on Corpulence, Addressed to the public. London: Harrison and Sons, 1863 .

Berland, Theodore and The Editors of Consumer Guide. Rating the Diets. New York: The New American Library, Inc., 1979.

Bray, George A. "The Myth of Diet in the Management of Obesity." The American Journal of Clinical Nutrition 23 (September 1979):1141-1148.

Brown, Stephen $W$. and Dimsdale, Parks B. "Consumer Information: Toward an Approach for Effective Consumer Knowledge Dissemination." The Journal of Consumer Affairs 7 (Summer 1973): 55-60. 
Bruch, Hilde. "The Allure of Food Cults and Nutrition Quackery.' Journal of The American Dietetic Association 57 (October 1970):316-320.

Charters, Margaret. Consumer Education Programming in Continuing Education. Syracuse University: Publications in Continuing Education and ERIC Clearinghouse on Adult Education. (January 1973).

Cook, Thomas D., Cook, Fay Lomax and Mark, Melvin M. "Randomized and Quasi-Experimental Designs in Evaluation Research: An Introduction." Evaluation Research Methods. Ed. by Leonard Rutman, Beverly Hills: Sages Publications, Inc., 1977.

[Darby, William J.] "The Unicorn and Other Lessons from History." Nutrition Reviews Supplement (July 1974): 57-61.

Deutsch, Ronald M. The New Nuts Among the Berries. Palo Alto, CA: Bull Publishing Co., 1977.

Drenick, Ernest J. and Johnson, Daisie. "Weight Reduction by Fasting and Semi-starvation in Morbid Obesity: Longterm Follow-up." International Journal of Obesity 2 (1978): 123-132.

Dudleston, Ann K. and Bennion, Marion. "Effect of Diet and/or Exercise on Obest Coollege Women." Journal of The American Dietetic Association 56 (February 1970): $126-129$.

Eppright, Ercel, Pattison, Mattie and Barbour, Helene. Teaching Nutrition, 2nd ed. Iowa: Iowa University Press, 1963.

Eppright, Ercel S., Fox, Hazel M., Fryer, Beth A., Lamkin, Glenna H. and Vivian, Virginia M. "The North Central Regional Study of Diets of Preschool Children. Part 2. Nutrition Knowleage and Attitudes of Mothers." Journal of Home Economics 62 (May 1970):327-332.

Family Circle, 24 April, 7 August, 15 December, 1978.

Feinstein, Alvan R. "The Treatment of Obesity: An Analysis of Methods, Results and Factors which Influence Success." Journal of Chronic Diseases 11 (April 1960):393-349.

Fletcher, Horace. The A.B.-Z. of Our Own Nutrition. New York: Frederick A. Stokes Company, 1903. 
Good Housekeeping, April, August, December 1978.

Graham, Sylvester. Lectures on the Science of Human Life. 2 Vols. Boston: Marsh, Capen, Lyon and Webb, 1839 .

Haag, Jessie Helen. Consumer Health: Products and Services. Philadelphia: Lea \& Febiger, 1976.

Herbert, Victor. "Facts and Fictions about Megavitamin Therapy:" Journal of the Florida Medical Association 66 (April 1979):475-481.

Himburg, Susan Phillips. "The Identification and Evaluation of Proposed Minimum Competencies for the Dietetic Technician in Patient Interviewing and Diet Counseling." Ph.D. Dissertation. University of Miami, 1979.

Isaac, Stephen and Michael, Willim B. Handbook in Research and Evaluation. San Diego: Robert R. Knapp. 1971.

Jalso, Shirley B., Burns, Majorie M. and Rivers, Jerry M. "Nutritional Beliefs and Practices." Journal of The American Dietetic Association 47 (October 1965):263-268.

Johnson, Clair Agriesti and Hurley, Roberta S. "Design and Use of an Instrument to Evaluate Students' Clinical Performance." Journal of The American Dietetic Association 68 (May 1976):450-453.

Kasper, H., Thiel H. and Ehl, M. 'Response of Body Weight to a Low Carbohydrate, High Fat Diet in Normal and Obese Subjects." American Journal of Clinical Nutrition 26 (February 1973):197-204.

The Ladies Home Journal, April, August, December 1978.

Lewis, Kathleen J. and Doyle, Margaret D. "Nutrient Intake and Weight Response of Women on Weight Control Diets." Journal of The American Dietetic Association 56 (February 1970):119-125.

Leverton, Ruth M. "The Merry-Go-Round of Reducing Diets." Journal of The American Dietetic Association 29 (April 1953):333-336. 
Mann, George. "The Influence of Obesity on Health: First of Two Parts." The New England Journal of Medicine 291 (July 25, 1974):178-185.

"The Influence of Obesity on Health: Second of Two Parts." The New England Journal of Medicine 201 (August 1, 1974):266-232.

Mayer, Jean. "Reducing by Total Fasting." Human Nutrition: Its Medical and Social Aspects, pp. 373-378. Springfield, Ill.: Charles C. Thomas, 1972.

"Weight Control and 'Diets': Facts and Fads." In The Health Robbers, pp. 47-59. Edited by Stephen Barrett and Gilda Knight., Philadelphia: George F. Stickley Company, 1976.

Merritt, Russell J. "Treatment of Pediatric and Adolescent Obesity." International Journal of Obesity 2 $(1978): 207-214$.

Miller, D. S. and Mumford, Pamela. "Gluttony 1. An Experimental Study of Overeating on Low-Carbohydrate, High-Protein Diets." The American Journal of Clinical Nutrition 20 (November 1967):1212-1222.

Munro, J. F. "Clinical Aspects of the Treatment of Obesity by Drugs: A Review." International Journal of Obesity 3, (1979):171-180.

Pacific Mutual Life Insurance Company, Health Maintenance Survey. Conducted by Louis Harris and Associates, Inc. Newport Beach, CA: Pacific Mutual Life Insurance Company, November 1978.

Pilkington, T.R.E., Gainsborough, H., Rosenoer, V. M., and Carey, M. "Diet and Weight Reduction in the Obese." Lancet 1 (April 16, 1960):856-858.

Preston, Ivan L. "Observations on Consumers' Use of the Mass Media." The Journal of Consumer Affairs 3 (Summer 1969): 59-72.

Redbook, April, August, December 1978.

Remmers, H. H. "Chapter 76. Rating Methods in Research on Teaching." In Handbook of Research on Teaching. Edited by N. L. Gabe. Chicago: Rand McNally \& Company. 1963. 
Schwartz, Nancy E. "Nutritional Knowledge, Attitudes and Practices of High School Graduates." Journal of The American Dietetic Association 66 (January 1975):28-31.

Sherrill, Robert. "Before You Believe Those Exercise and Diet Ads Read the following Report." Today's Health 49 (August 1971):34-36, 68-70.

Smith, Patricia Cain and Kendall, L. M. "Retranslation of Expectations: An Approach to the Construction of Unambiguous Anchors for Rating Scales." Journal of Applied Psychology 47 (April 1963):149-155.

Sohar, Ezra and Sneh, Ephraim. "Follow-up of Obese Patients 14 Years After a Successful Reducing Diet." The American Journal of Clinical Nutrition 26 (August 1973): 845-848.

Sproles, George B., Geistfeld, Loren V. and Badenhop, Suzanne B. "Informational Inputs as Influences on Efficient Consumer Decision-Making." The Journal of Consumer Affiars 12 (Summer 1978):88-103.

Stanley, Thomas J. "Nutritional Information and Preferences for Breakfast Cereals." The Journal of Consumer Affairs 11 (Winter 1977):121-126.

Stare, Frederick J. "Current Nutrition Nonsense in the United States." In Symposia of the Swedish Nutrition Foundation VIII: Food Cultism and Nutrition Quackery, pp. 51-58. Edited by Gunnar Blix. Uppsala, Sweden: Almqvist \& Wiksells, 1970.

Stillman, Irwin Maxwell and Baker, Samm Sinclair. The Doctor's Quick Weight Loss Diet. New York: Dell Publishing Co., 1967.

Stunkard, Albert J. "New Therapies for the Eating Disorders." Archives of General Psychiatry 26 (May 1972) : 391-398.

Thorelli, Hans B. and Thorelli, Sarah V. Consumer Information Systems and Consumer Policy. Cambridge, MA: Ballinger Publishing Company, 1977.

Todhunter, E. Neige. "Food Habits, Food Faddism and Nutrition." World Review of Nutrition and Dietetics: Food, Nutrition and Health 16 (1973):287-317. 
Tower, Joyce B. and Vosburgh, Paula M. "I. Theoretical Considerations and Method of Construction. Development of a Rating Scale to Measure Leaning in Clinical Dietetics." Journal of the American Dietetic Association 68 (May 1976):440-445.

Tullis, I. Frank. "Rational Diet Construction for Mild and Grand Obesity." Journal of the American Medical Association 226 (October 1, 1976):70-71.

Van Itallie, Theodore B. "Diets for Weight Reduction: Mechanisms of Action and Physiological Effects." International Journal of Obesity 2 (1978):113-122.

Walker, Jerry. "What's Wrong (Right) With Evaluation?" In Proceedings of The National Research Conference on Consumer and Homemaking Education. Columbus, Ohio: The Ohio State University. October 1970. Pp. 32-37.

Wilson, Mary Margaret and Lamb, Mina W. "Food Beliefs: As Related to Ecological Factors in Women." Journal of Home Economics 60 (February 1968):115-118.

Woman's Day, 7 August, 19 December, 1978.

Yang, Mei-Uih and Van Itallie, Theodore B. "Composition of Weight Lost During Short-term Weight Reduction." The Journal of Clinical Investigation 58 (September 1976): 722-730.

Young, Charlotte M., Waldner, Betty Greer, and Berresford, Kathleen. "What the Homemaker knows About Nutrition. I. Description of Studies in Rochester and Syracuse, N.Y." Journal of The American Dietetic Association 32 (September 1956):214-217.

"What the Homemaker knows About Nutrition. IV. Her Food Problems, Shopping Habits, and Sources of Information." Journal of The American Dietetic Association 32 (May 1956):429-434.

Young, James Harvey. "Historical Aspects of Food Cultism and Nutrition Quackery." In Symposia of the Swedish Nutrition Foundation VIII: Food Cultism and Nutrition Quackery. Edited by Gunnar Blix. Uppsala, Sweden: Almqvist \& Wiksells, 1970.

Yudkin, J. and Carey, M. "The Treatment of Obesity by the "High-fat" Diet. The Inevitability of Calories." Lancet 2 (October 29, 1969):939-941. 